\title{
Extracellular Vesicles in Advanced Prostate Cancer: Tools to Predict and Thwart Therapeutic Resistance
}

\author{
Carolina Saldana ${ }^{1,2,+}$, Amene Majidipur ${ }^{1, \dagger}$, Emma Beaumont ${ }^{1}$, Eric Huet ${ }^{1}{ }^{1}$, Alexandre de la Taille ${ }^{1,3}$, \\ Francis Vacherot ${ }^{1}$, Virginie Firlej ${ }^{1, \neq(1)}$ and Damien Destouches ${ }^{1, *, \neq(1)}$ \\ 1 Univ Paris Est Creteil, TRePCa, F-94010 Creteil, France; carolina.saldana@aphp.fr (C.S.); \\ ami.majidi14@gmail.com (A.M.); emma.beaumont@orange.fr (E.B.); huet@u-pec.fr (E.H.); \\ alexandredelataille@gmail.com (A.d.1.T.); vacherot@u-pec.fr (F.V.); virginie.firlej@u-pec.fr (V.F.) \\ 2 AP-HP, Hopital Henri-Mondor, Service Oncologie, F-94010 Creteil, France \\ 3 AP-HP, Hopital Henri-Mondor, Service Urologie, F-94010 Creteil, France \\ * Correspondence: damien.destouches@u-pec.fr; Tel.: +33-(0)1-49-81-36-14; Fax: +33-(0)1-49-81-39-00 \\ + These authors contributed equally to this work. \\ $\ddagger$ These authors contributed equally to this work.
}

Citation: Saldana, C.; Majidipur, A.; Beaumont, E.; Huet, E.; de la Taille,

A.; Vacherot, F.; Firlej, V.; Destouches,

D. Extracellular Vesicles in Advanced Prostate Cancer: Tools to Predict and Thwart Therapeutic Resistance. Cancers 2021, 13, 3791. https:// doi.org/10.3390/cancers13153791

Academic Editor: David Wong

Received: 31 May 2021

Accepted: 23 July 2021

Published: 28 July 2021

Publisher's Note: MDPI stays neutral with regard to jurisdictional claims in published maps and institutional affiliations.

Copyright: (c) 2021 by the authors. Licensee MDPI, Basel, Switzerland. This article is an open access article distributed under the terms and conditions of the Creative Commons Attribution (CC BY) license (https:/ / creativecommons.org/licenses/by/ $4.0 /)$.
Simple Summary: Advanced prostate cancer remains currently an important cause of cancer death. Despite the emergence of new treatments during the last decade, their efficiency is limited due to therapeutic resistance of tumor cells. Extracellular vesicles are secreted by cells and play an important role in cell-cell communications. Their content is specific to the cell that produced them, and they can be isolated from biological fluids such as blood and urine. In this review, we highlight the recent results demonstrating the impact of extracellular vesicles in the mechanisms leading to therapeutic resistance and their use to find new predictive biomarkers in order to facilitate treatment decision and personalized medicine.

Abstract: Prostate cancer (PCa) is the second most frequent cancer and the fifth leading cause of cancer death among men worldwide. At first, advanced PCa is treated by androgen deprivation therapy with a good initial response. Nevertheless, recurrences occur, leading to Castrate-Resistance Prostate Cancer (CRPC). During the last decade, new therapies based on inhibition of the androgen receptor pathway or taxane chemotherapies have been used to treat CRPC patients leading to an increase in overall survival, but the occurrence of resistances limits their benefits. Numerous studies have demonstrated the implication of extracellular vesicles (EVs) in different cancer cellular mechanisms. Thus, the possibility to isolate and explore EVs produced by tumor cells in plasma/sera represents an important opportunity for the deciphering of those mechanisms and the discovery of biomarkers. Herein, we summarized the role of EVs in therapeutic resistance of advanced prostate cancer and their use to find biomarkers able to predict these resistances.

Keywords: prostate cancer; extracellular vesicles; therapeutic resistances; predictive biomarkers

\section{Introduction}

In 2018, prostate cancer (PCa) incidence worldwide was estimated at 1.3 million new cases, associated with 359,000 deaths, ranking PCa as the second most frequent cancer and the fifth leading cause of cancer death among men [1].

Therapeutic approaches and prognosis of PCa depend on its stage at diagnosis (Figure 1). In $70 \%$ of cases, the diagnosis occurs when the tumor is localized in the prostate gland and $20 \%$ are diagnosed at the locally advance stage. Treatment of these tumors by surgery or radiotherapy guarantees a high survival rate. Nevertheless, despite the best standard of care treatment, one third of localized/locally advanced prostate cancer will relapse. In addition, in 5 to $10 \%$ of PCa, diagnosis occurs at the metastatic stage. 

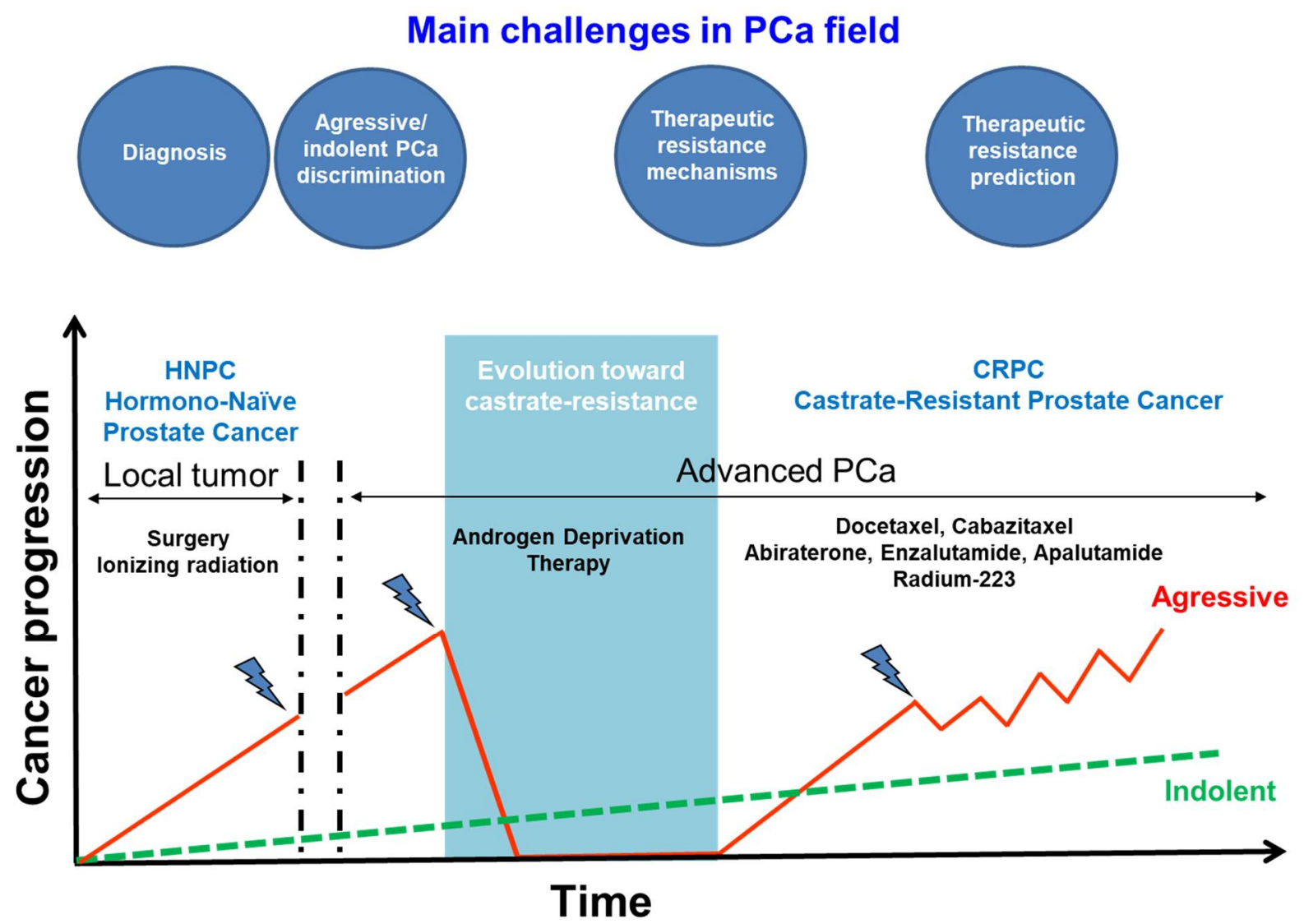

Figure 1. Clinical evolution of PCa and the main challenges for research.

At a metastatic stage or after a progression from a localized tumor to a metastatic stage, patients enter into the advanced PCa phase (Figure 1). Androgen-deprivation therapy (ADT; i.e., LHRH antagonists or agonists) is the gold standard treatment, since prostate tumor cells are dependent on androgens to survive and grow at this stage [2]. Improved outcomes were observed by several practice-changing trials in an advanced setting such as the addition of androgen receptor pathway inhibitors (ARPIs) or docetaxelbased chemotherapy in combination with ADT [3-5]. However, during ADT, metastatic castrate-resistant prostate cancer (mCRPC) irremediably emerges because tumor cells adapt in order to survive and grow (PSA or radiological progression) despite a low blood level of testosterone [6]. Since 2004, first-line chemotherapy for the treatment of mCRPC essentially includes the docetaxel taxane, that inhibits microtubular depolymerization, in combination with ADT [7,8]. Since 2015, this therapy is also used for ADT untreated metastatic cancer, named metastatic hormonal sensitive or hormonal naïve cancer (mHSPC), improving progression-free survival (PFS) and an overall survival (OS) $[3,4,9]$. Additionally, Cabazitaxel, a second-generation semisynthetic taxane, is currently restricted for treatment of men with mCRPC with a disease which has progressed during or after docetaxel-based therapy [10]. Cabazitaxel failed to show survival benefit in the first-line setting compared to docetaxel [11].

Among androgen receptor pathway inhibitors (ARPIs), two groups can be described: those suppressing androgen biosynthesis (abiraterone) [12] and those blocking AR (enzalutamide, apalutamide and darolutamide) [13]. Abiraterone acetate and enzalutamide have demonstrated significant benefits in terms of OS and PFS either for chemo-naïve and locally advanced CRPC, mHSPC or in a post-docetaxel setting [14-21]. Concerning Apalutamide, a recent phase III trial led to its approval in mHSPC [22]. Finally, radionuclides such as radium 223 showed improved survival rates with minor bone marrow damage in $\mathrm{mCRPC}$ with bone-only metastasis [23]. 
Metastatic CRPC patients were expected to survive from 16 to 18 months [24]. Despite the emergence of these new drugs, the increased median survivals due to these new therapies ranged only from 1.9 to 8.2 months $[7,8,10,14,15,18,20]$. A part of the patients presents primary resistance: one third are refractory to docetaxel or abiraterone and one fourth to enzalutamide $[8,14,18]$. Furthermore, mCRPC tumor cells acquire additional resistances leading to patient death. Therefore, understanding the mechanisms of treatment resistance or sensitivity can help to achieve a more effective management of mCRPC to ensure better outcomes by limiting side effects and costs of unnecessary treatments or procedures. In addition, it could lead to the identification of potential therapeutic targets to prevent the emergence of such resistance.

Four main challenges must be solved in PCa (Figure 1). First, some patients are still diagnosed at the metastatic stage. New tools are needed to allow earlier detection. Secondly, as an indolent form of PCa is known to be livable without treatment and treating it could cause unnecessary side effects, indolent and aggressive PCa need to be discriminated. This makes biomarkers research an important axis in PCa. Additionally, to avoid unnecessary side effect of chemotherapy or ARPIs, identification of biomarkers predictive of therapeutic response remains very important to help practitioners in therapeutic decisions. Finally, as therapeutic resistances occur in advanced $\mathrm{PCa}$, the understanding of resistance mechanisms should allow one to identify new molecular targets and define new therapeutic strategies to thwart them.

In this context, extracellular vesicles (EVs) may appear as very promising tools. Indeed, most cell types, including cancer cells, secrete EVs. They contain molecules such as DNA, RNA, proteins, lipids or metabolites reflecting the content of the cell from which they are derived. Furthermore, in pluricellular organisms, EVs can be isolated from different body fluids including blood, plasma/serum and urine, making them a powerful and accessible source of biomarkers [25].

In this review, we highlight the roles of EVs in therapeutic resistance mechanisms in an advanced PCa context and their promising use to discover new predictive biomarkers.

\section{Extracellular Vesicles: Generalities}

The concept of EVs has been first reported in 1946 as "procoagulant platelet-derived particles" and later as "platelet dust" circulating in the plasma [26,27]. Exosomes were then described in the 1980's as EVs involved in the transport of the transferrin receptor out of reticulocytes during their maturation [28-30]. They were considered as artifacts or a trash bin for unnecessary and redundant proteins [31,32]. The International Society of Extracellular Vesicles currently defines EVs as "particles naturally released from the cell that are delimited by a lipid bilayer and cannot replicate, i.e., do not contain a functional nucleus" [33].

EVs represent a large and heterogeneous group of vesicles referenced under different names such as exosomes, ectosomes, microvesicles, oncosomes, prostasomes or exosomelike vesicles, depending on their tissue/cell of origin, nature, size or proposed function [34]. Based on the current knowledge of their biogenesis, EVs can be divided into two main groups: ectosomes/microvesicles and exosomes [35]. Ectosomes/microvesicles are produced by shedding from the plasma membrane. The activation of the plasma membrane is associated with intracellular calcium influx, mediated by ARF- 6 and interactions between cytoskeletal resident proteins actin and myosin [36]. In general, they display a range of size from $50 \mathrm{~nm}$ to $1 \mu \mathrm{m}$. A subgroup of microparticules produced by tumor cells is called large oncosomes (LO). They were first described in prostate cancer, and they display an important size from 1 to $10 \mu \mathrm{m}[37,38]$. LO have been detected in tumor tissues and plasma from PCa patients and can contain DNA fragments [38].

Exosomes have an endosomal origin and are produced during maturation of multivesicular endosomes (MVEs) through intracellular budding of late endosomes generating intra-luminal vesicles (ILVs) $[34,39]$. Most of the MVEs are degraded after fusion with lysosomes but some of them fuse with the plasma membrane to release their content, the 
exosomes, in the extracellular compartment. The biogenesis of exosomes remains complex and depends on cell types and cargo transports [35]. Exosomes can be produced through the Endosomal Sorting Complex Required for Transport (ESCRT) machinery or through an ESCRT-independent pathway with the lipid ceramides or proteins from the tetraspanin family $[40,41]$.

Since no consensus has been established concerning specific markers for determining the origin of EVs (exosome or ectosome), the International Society of Extracellular Vesicles (ISEV) advises now to use the generic term of EVs instead of exosomes or ectosomes. This generic term of EVs should be accompanied with an operational term referring to their size (small, medium, large) or density (low, medium or high) characteristics, composition (CD63+, CD9+, CD81+, Annexin A5, .. ) or origin (large oncosomes, apoptotic bodies, ... ) [33].

Methods to isolate EVs are based on their biophysical and biochemical properties. U1trafiltration, differential centrifugation, density gradient centrifugation and size exclusion chromatography allow EV isolation due to their size and their density properties. Different EV purification kits are often polyethylene glycol based leading to EV precipitation in combination with low speed centrifugation. Other methods take advantage of EV antigen presence for their immunocapture with specific antibodies [42]. Currently, there is no standard method to isolate EVs without contaminants including soluble proteins, protein aggregates, lipoproteins and other particles such as viruses or organelles. The choice of the method should take into account the balance between the desired purity and concentration of EVs. Isolated EVs have to be characterized to determine their size, concentration, content and the presence of contaminants as recommended by the ISEV [33].

EVs are now considered as part of cell-cell communication system. Indeed, EVs allow the transfer of molecules such as DNA fragments, RNA, proteins, lipids or metabolites from an emitting cell to a recipient one. Furthermore, EVs appear as a promising biomarkers source since they can be isolated from different bodily fluids in pluricellular organisms including blood and plasma/serum [25,43,44], urine [45], saliva [46], breast milk [47], amniotic fluid, ascites, cerebrospinal fluid, bile, nasal secretions [48], feces [49] and semen [50].

Production of EVs from normal prostate cells has been described in the late 1970s. These EVs were called prostasomes and their origin (exosomes or microvesicles) is still a matter of debate [51]. Prostasomes display a range of size from 50 to $500 \mathrm{~nm}$ with a mean about $150 \mathrm{~nm}$ [52]. They can be isolated from seminal plasma [53] and urine [54] and can be produced by prostate cancer cells [55].

Accumulating evidence from the last decade, publications suggests a significant role of EVs in the hallmarks of cancer [56]. EVs were shown to be able to induce PCa cell proliferation [57-59], to promote the metastasis process through the acquisition of migration and invasion properties [60-62] and to block the immune system [63].

\section{Role of EVs in Therapeutic Resistance in Advanced Prostate Cancer 3.1. Modulation of the AR Pathway}

The androgen receptor (AR) axis plays a key role in the development of mCRPC. Most of the known mechanisms are based on the reactivation AR pathway despite a low level of blood testosterone, including AR gene mutation, emergence of AR splice variants, amplification and overexpression of the AR protein or intraprostatic production of androgens by tumor cells themselves [64]. Other mechanisms described are based on crosstalk with alternative signaling pathways [65].

Recent studies have suggested that EVs from tumor cells may transport AR and its variants to recipient cells [57]. These EVs containing AR were able to activate the expression of AR-responsive genes, as AR from EVs can bind to the enhancer region of PSA and increase RNA polymerase II occupancy. Therefore, these EVs promoted proliferation of LNCaP cells in the absence of androgen. A link between EVs and ADT resistance was proposed by Soekmadji et al. EVs were isolated from androgen-dependent LNCaP cells that were deprived 
of androgen or treated with the AR inhibitor enzalutamide. Proteomic analysis of these EVs highlighted the crosstalk between AR signaling, EV secretion pathways and calcium homeostasis, participating in the enzalutamide resistance [66]. Recently, Zhang et al. have demonstrated that LNCaP cells treated with EVs from androgen-independent cells (PC3) were able to acquire androgen-independent features with increased proliferation observed in both androgen-supplied and androgen-deprived medium [67]. Increased tumor growth of such treated cells was confirmed in vivo in intact and castrated NOD/SCID mice. The acquisition of the androgen-independent state was associated with a decrease in AR and PSA expression and an up-regulation of HMOX1 [68]. This up-regulation of HMOX1 was reported to be responsible for the acquisition of the androgen-independent state [67]. These studies suggest a role of EVs in the emergence of the MCRPC state after ADT (Figure 2); however, the mechanisms remain poorly investigated.

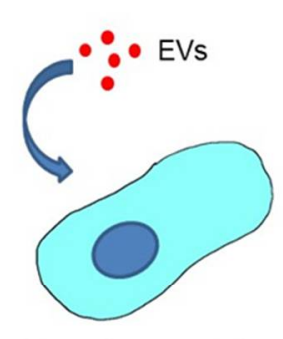

Sensitive prostate tumor cell

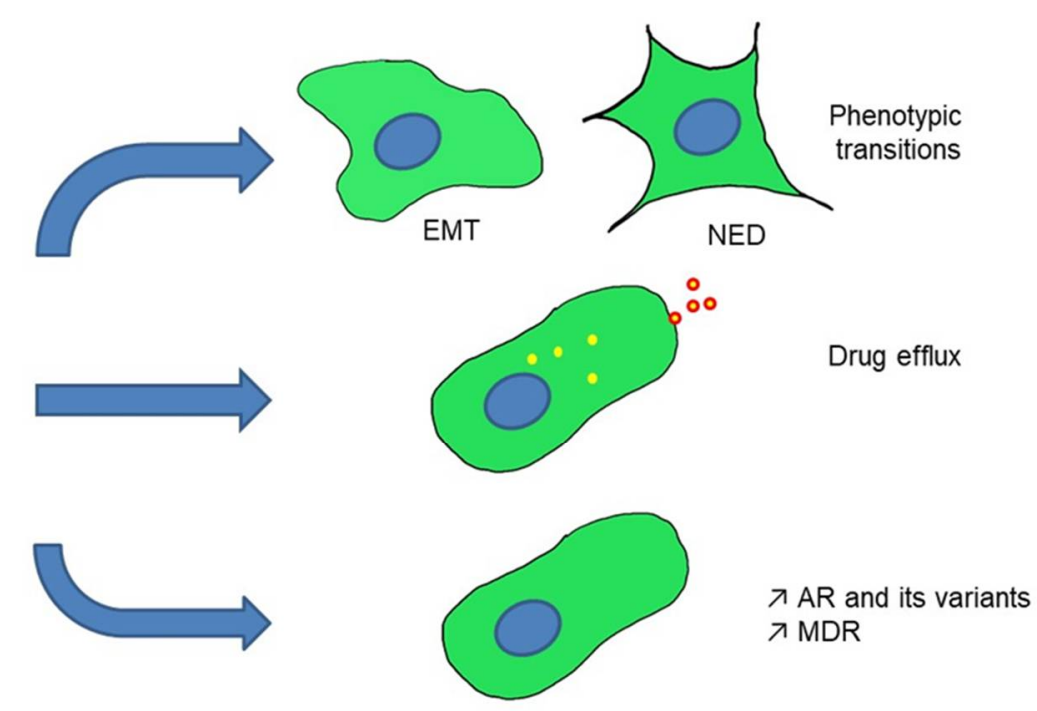

Resistant prostate

tumor cell

Figure 2. The main mechanisms of therapeutic resistance induced by EVs in prostate tumor cells. Roles of EVs have been demonstrated in the induction of tumor plasticity, elimination of drug inducing drug efflux or augmentation of gene expression or protein/mRNA transfer via EVs. EMT = Epithelial to Mesenchymal Transition, NED = Neuroendocine Differentiation, $\mathrm{AR}=$ Androgen Receptor and MDR $=$ Multi Drug Resistance.

One of the mechanism responsible for ADT and ARPIs resistance is the emergence of AR splicing variants (AR-Vs). Endogenous expression of AR-Vs in PCa cell lines was first reported in the early 2000s [69]. Currently, more than $20 \mathrm{AR}-\mathrm{Vs}$ have been described and most of them exhibit a truncated $\mathrm{COOH}$-terminal ligand-binding domain (LBD) with a remaining ability to bind DNA leading to a constitutive activation despite the absence of ligands [70]. AR splice variant-7 (AR-V7) is the most investigated variant accountable for ADT and ARPIs resistance of PCa tumor cells [71].

Full-length AR and its AR-V7 variant proteins were recently detected in EVs isolated from tumor prostate cell lines LNCaP and 22RV1 [57]. The treatment of AR negative PC 3 cells with EVs isolated from AR positive 22RV1 cells led to a binding of AR to its promotor region and to the transcription activation of AR responsive genes demonstrating the AR transfer via EVs. Moreover, transfer of AR and AR-V7 to androgen-responsive cells promoted cell proliferation [57]. Presence of full-length AR and AR-V7 was confirmed in EVs from plasma of PCa patients [72-74].

These results highlight the role of EVs in the transfer of ARPIs resistance through AR and its AR-V7 variant (Figure 2). 


\subsection{EVs and Chemotherapy Resistance Transfer}

The role of EVs in cancer resistance to chemotherapy was first suggested with the observation of a positive correlation between expression of membrane shedding-related genes by tumor cells and their profile of chemotherapy resistance [75]. The anticancer drug doxorubicin was found to be accumulated in the EVs of different cell lines, including PC3, suggesting a role of drug efflux leading to drug resistance. Based on this, inhibition of EVs production was associated with increased sensitivity to chemotherapy. Indeed, inhibition of EVs production with EV biogenesis inhibitor (chloramine and bisindolylmaleimide-I) led to increased concentration of 5-Fluorouracile (5-FU) inside PC3 cells, associated with increased apoptosis and inhibition of 5-FU resistance [76]. Inhibition of EVs production using the calpain inhibitors (Calpeptin) and siRNA, showed higher intracellular retention of docetaxel associated with a decrease in its $\mathrm{GI}_{50}$ and reduced tumor volume in PC3 ectopic xenograft in mice [77].

The most investigated mechanism to explain resistance to chemotherapy remains the overexpression of multidrug resistance (MDR) genes, also called ATP-binding cassette $(A B C)$ transporter genes. The transporter proteins encoded by these genes play the role of a molecular pump leading to a decrease in the intracellular concentration of drugs. Several MDR proteins such as ABCB1 (or MDR1/P-glycoprotein), ABCC4 or ABCC5 are overexpressed in PCa cells, contributing to taxane resistance [78,79]. Lucotti et al. have demonstrated that treatment of DU145 cells with fludarabin decreased hsa-miR-485-3p in EVs with its cell retention leading to inhibition of the transcription factor NF-YB associated with an increase in MDR-1 expression and fludarabin resistance [80].

To investigate the role of EVs in chemoresistance, tumor prostate cell lines were treated with chemotherapy agents until the acquisition of resistance. Several studies followed the strategy consisting of EVs isolation from the different cell lines, and treatment and observation of sensitivity/resistance to chemotherapy transfer between cells. Via this strategy, EVs protein content was compared between docetaxel sensitive and resistant DU145 prostate tumor cell lines. Among the protein differentially present in the EVs from the two different cell lines, MDR-1 and MDR-3 proteins, involved in drug efflux, were found enriched in the EVs of docetaxel-resistant cells [81]. Corcoran et al. used EVs isolated from docetaxel-resistant 22RV1 and DU145 cell line variants. Treatment of the parental 22RV1 and DU145 cell lines with these EVs did not modify cell proliferation, migration or invasion but was able to confer to them resistance to docetaxel. Furthermore, EVs isolated from sera of patients undergoing docetaxel treatment were also able to transfer docetaxel resistance to DU145 and 22RV1 cells when patients displayed docetaxel resistance. One mechanism of docetaxel resistance was the transfer of MDR-1/P-glycoprotein via the EVs [82].

A similar study has demonstrated that camptothecin-sensitive DU145 cells treated with EVs isolated from camptothecin-resistant DU145 cells acquired a higher resistance to camptothecin, observed by a resistance to apoptosis linked to reduced cleaved PARP [83]. In the inverse strategy, EVs were isolated from non-malignant prostate cells and human mesenchymal stem cells (RWPE-1 and MSCs) and used to treat a paclitaxel resistant DU145 cell line. EVs from both non-malignant cell lines were able to reverse the resistant phenotype of paclitaxel resistant DU145 cells: those cells subsequently encountered apoptosis when treated by EVs [84]. Using two prostate tumor cell lines resistant to enzalutamide, C4-2B and CWR-R1, it was demonstrated that resistant cells produced more EVs than their parental counterparts. Mechanistic studies indicated that syntaxin was over-expressed in resistant cells compared to the sensitive one and could be responsible for the increase in EVs production [85]. EVs from PC3 and DU145 docetaxel resistant cells were isolated and their content in miRNA was analyzed using the miRNA microarray chip. Bioinformatic analysis permitted one to identify the miRNAs able to regulate AR, PTEN and TCF4 genes and to confer resistance to docetaxel. miR3176, -141-3p, -5004-5p, -16-5p, -3915, -488-3p, $-23 c,-3673$ and -3654 regulated AR and PTEN whereas TCF4 is a target of miR-32-5, -141-3p, $-606,-381$ and -429 [86]. 
All these results determine that EVs are able to transfer resistance information to therapeutic sensitive cells (Figure 2). The understanding of involved mechanisms is critical to develop strategies to block these cell-to-cell communications.

\subsection{Lineage Plasticity (NED and EMT)}

One of the therapeutic resistance mechanisms described in $\mathrm{mCRPC}$ is the emergence of a high rate of tumor cell heterogeneity. Androgen deprivation has been shown to activate both epithelial-to-mesenchymal transition (EMT) and neuroendocrine trans-differentiation (NED) programs.

EMT is well known for the promotion of biological phenotypes associated with tumor progression (migration/invasion, tumor cell survival, cancer stem cell-like properties and resistance to radiation and chemotherapy) in multiple human cancer types [87].

In previous studies, we have generated a prostate tumor cell line derived from the 22RV1 cell line and named Mes-22RV1 [88]. This new cell line had undergone the EMT process and displayed mesenchymal features. These Mes-22RV1 cells produce more EVs compared to 22RV1 parental cells. The role of EVs isolated from these mesenchymal prostate tumor cells in the induction of EMT in epithelial VCaP cells was then investigated [89]. Recipient epithelial VCaP cells treated with EVs from the mesenchymal cells gained mesenchymal features accompanied with inhibition of AR expression and activity, increase in EMT markers (SNAI1, SNAI2, VIM, CDH2, PAI1 and FN1) and higher migration and invasion capacities. All these effects were associated with an increased resistance to enzalutamide [89]. Recently, it has been shown that EVs can deliver caveolin-1 into PCa cells leading to the cancer stem cell (CSC) phenotype. In LNCaP cells, caveolin-1 induces EMT through activation of the NFKB signaling pathway. This process, due to EMT induction, was associated with increased expression of ZEB1, ZEB2, Slug, Twist, vimentin and downregulated E-cadherin expression. Furthermore, LNCaP cells treated with caveolin-EVs exhibited an increase in migration and invasion capacities as well as higher resistance to docetaxel and radiotherapy. EMT induction was confirmed by overexpression of vimentin and downregulation of E-cadherin in Caveolin overexpressed LNCaP. Decreasing caveolin-1 expression using shRNA produced opposing results, confirming thus the role of caveolin-1 [90].

NED in prostate cancer is associated with resistance to therapy, visceral metastasis and aggressive disease. Thus, activation of such programs via the inhibition of the androgen axis provides a mechanism by which tumor cells can adapt to promote disease recurrence and progression [91-93].

The role of EVs in NED through the transfer of adipocyte differentiation-related protein (ADRP) was reported [94]. Inducing NED with IL-6 treatment or androgen deprivation led to increased expression of ADRP and packaging in EVs. ADRP overexpressing EVs triggered NED in C4-2 and DU145 cells. Furthermore, EVs isolated from C4-2B cells resistant to enzalutamide contain a higher amount of ADRP [94]. Recently, Bhagirath et al. have demonstrated the role of Pro-neural Pou-domain transcription factors, BRN4 and BRN2, in the induction of the neuroendocrine phenotype using IL-6 treatment [95]. During NED induction with IL-6 treatment, LNCaP cells produced more EVs. These EVs contained BRN4 and BRN2 mRNA. It has to be specified that these two mRNAs were also detected overexpressed in blood EVs from CRPC patients with neuroendocrine features. Enzalutamide treatment was also shown to enhance the release of BRN4 and BRN2 mRNA in PCa EVs, and treatment of LNCaP cells with these EVs promoted NED induction [95].

Accumulated treatment pressure in mCRPC patients increases the rate of tumor heterogeneity leading to highly resistant tumors [96]. These studies demonstrate the key role played by EVs in the establishment of tumor heterogeneity through EMT and NED leading to therapeutic resistance (Figure 2). 


\subsection{Role of the Microenvironment}

The microenvironment of tumors is composed of different cell types such as cancer associated fibroblast (CAF), tumor associated macrophages (TAM), pericytes, immune and endothelial cells. All these cell types are known to be involved in therapeutic resistance [97].

Only a few studies have addressed the question of the role of EVs from the tumor microenvironment in PCa therapeutic resistance. Zhang et al. have studied the impact of EVs produced by primary CAF from PCa patients under ADT conditions on PCa tumor cells behavior. LNCaP and DU145 cells treated with these EVs displayed higher migration and invasion capacities associated with EMT process induction through a decrease in miR146a-5p exosomal transfer from CAF to PCa cells under ADT. Confirming the in vitro results, the expression of miR-146a-5p was lower in the tumors of patients who received ADT compared to the tumors of patients who underwent surgery without ADT therapy [98]. Exosomes isolated from PSC-27cells (primary prostate fibroblasts) and added to PC3 cells induced chemotherapy resistance with increased $\mathrm{IC}_{50}$ values of 0.3 fold for cisplatin, 0.4 fold for doxycycline and 1.3 for docetaxel. This induced resistance was due to miR-27a derived exosomes that regulated the expression of Trp53 [99]. A third study showed that CAF-secreted exosomal miR-423-5p promoted resistance to docetaxel or bicalutamide in PCa cells LNCaP, 22RV1 and C4-2 cells, respectively, by targeting GREM2 [100].

\section{EVs as Source of Biomarkers to Predict Therapeutic Resistances in PCa}

\subsection{EVs Content to Find New Predictive Biomarkers}

EVs can be isolated from different biological fluids and their content reflects the one of the cell producing them. Consequently, they can be used as biomarkers sources for $\mathrm{PCa}$ diagnostic, prognostic and predictive response to treatments $[52,101]$. Concerning predictive response biomarkers, it is essential to note the difficulty of finding them within prostate tumor tissues since biopsies are not recommended in patients with advanced PCa. In this context, EVs isolated from liquid biopsies such as serum, plasma and urine, appear as an attractive source of material especially for prostate cancer personalized medicine. Over the past decade, urinary and blood based biomarkers from EVs have been described and used for diagnosis as well as for tumor progression prediction [102,103]. Among those biomarkers, some have been documented in relation to therapeutic resistances in PCa (Table 1).

By producing docetaxel resistant cells from prostate tumor cell lines, P-gp/MDR1 was demonstrated to be increased in EVs from docetaxel resistant prostate cells (PC-3, 22RV1, DU-145) as compared to those from parental cells [82,104]. These results were confirmed in blood EVs from docetaxel resistant patients as compared to blood EVs from therapy-naïve or sensitive patients $[81,104]$. In addition, the copy number of CD44v8-10 mRNA was higher in EVs isolated from the serum of docetaxel-resistant patients compared to those of docetaxel-naïve and control patients, whereas it was not observed for CD44 mRNA [105]. AR splice variants, especially AR-V7, are associated with the resistance to ARPIs and taxane based treatments. Presence of AR-V7 mRNA variant in EVs from PCa patients was demonstrated using plasma samples. AR-V7 mRNA in EVs was associated with faster resistance to gold standard therapies in CRPC patients [72,73]. Moreover, the presence of AR-V7 mRNA variant in EVs allowed one to distinguish responders from non-responders to diverse therapies such as abiraterone, enzalutamide, cabazitaxel and docetaxel [106]. In another study, the double positivity for AR gain function (based on cfDNA) and AR-V7 mRNA (ddPCR on EVs) was related to shorter PFS and overall survival on abiraterone and enzalutamide treated CRPC patients [107]. ITGB4 and vinculin have been outlined as upregulated in taxane resistant $\mathrm{PC} 3$ and could be potential biomarkers for aggressive tumors, although no clinical studies have been carried out on these markers [108]. TSP1 was revealed to be expressed in EVs derived from LNCaP-AR-Enzalutamide resistant cells and NCI-H660 cells in contrast to EVs from LNCaP-AR cells. This protein level was also increased in EVs purified from sera of CRPC patients with neuroendocrine features. These results suggest that TSP1 could be employed as a biomarker to predict resistance to ARPIs 
and to diagnose NED in CRPC patients [109]. Another study described the expression of YAP1 and COUP-TFII in EVs from LNCaP-Enzalutamide resistant cells as well as sera from patients resistant to enzalutamide [110].

Regarding resistance to radium-223, transcriptome analysis of EVs from treated patients revealed a change in bone-related pathways as well as DNA damage repair and immune checkpoint. Notably, PD-L1 expression is associated with a short survival to Radium-223 [111].

miRNAs could also be used as biomarkers for prostate cancer [101]. Nevertheless, only a few miRs were described as predictive biomarkers for therapies resistance in prostate cancer. miR-34a level was decreased in both cells and EVs of two docetaxel resistant cell lines (22Rv1RD and PC3RD). This miR-34a was significantly diminished in prostate cancer vs. normal tissue, in biochemical recurrence vs. non-recurrence tissue and in metastatic tissue vs. primary site. However, clinical resistance has not been explored [112]. A miR-array study has also identified 29 deregulated miRNAs, 19 upregulated and 10 downregulated, in EVs samples derived from two paclitaxel resistant PCa cells (PC3 and DU145) compared with their parental cells, but miR expression in patients has not been investigated [86]. miR-21 expression was increased in EVs from enzalutamide resistant LNCaP cells as well as in sera of enzalutamide resistant patients [110].

In conclusion, some biomarkers, listed in Table 1, have been reported in EVs from therapy resistant tumors and cells. However, nowadays, no useable signatures in the clinical test existed. Thus, the field remains open for research.

Table 1. List of biomarkers from EVs studied to be predictive of resistance/sensitivity to advanced PCa therapies. In bold miRNA were verified by RT-qPCR. Abbreviations: for EVs isolation, UC = Ultracentrifugation, SEC = Size Exclusion Chromatography, UF = Ultrafiltration; for analysis methods, $\mathrm{ddPCR}=$ droplet digital PCR, TLDA = Taqman Low Density Array.

\begin{tabular}{|c|c|c|c|c|c|c|c|}
\hline $\begin{array}{c}\text { Header Analyzed } \\
\text { molecules }\end{array}$ & $\begin{array}{l}\text { Up/Down in } \\
\text { Resistant } \\
\text { Cells or } \\
\text { Tumors }\end{array}$ & $\begin{array}{l}\text { Analysis } \\
\text { Methods }\end{array}$ & $\begin{array}{c}\text { EVs } \\
\text { Isolation }\end{array}$ & $\begin{array}{l}\text { Origin of } \\
\text { Cells EVs }\end{array}$ & $\begin{array}{c}\text { Origin of } \\
\text { Patients EVs }\end{array}$ & Drug & Reference \\
\hline \multicolumn{8}{|c|}{ miRNA (bold: verified by RT-qPCR) } \\
\hline $\begin{array}{c}\text { hsa-miR-16-5p, } \\
\text { miR-203a, miR-32-5p, } \\
\text { miR-515-3p, miR-99b-5p, } \\
\text { miR-451a, miR-1204, } \\
\text { miR-4291, miR-4291, } \\
\text { miR-3673, miR-23c, } \\
\text { miR-3654, miR-3607-3p, } \\
\text { miR-3915, miR-4716-3p, } \\
\text { miR-4722-5p, miR-488-3p, } \\
\text { miR-4669, miR-5004-5p }\end{array}$ & Up & $\begin{array}{l}\text { Microarray } \\
\text { chip analysis } \\
\text { validated by } \\
\text { RT-qPCR }\end{array}$ & UC & $\begin{array}{l}\text { DU145 and } \\
\text { PC3 }\end{array}$ & & Paclitaxel & $\begin{array}{l}\text { Li et al., } \\
2016\end{array}$ \\
\hline $\begin{array}{l}\text { miR-141-3p, miR429, } \\
\text { miR192-5p, miR192-3p, } \\
\text { miR-606, miR-3176, } \\
\text { miR-1224-3p, miR-381-3p, } \\
\text { miR-933, miR-34b-3p }\end{array}$ & Down & $\begin{array}{l}\text { Microarray } \\
\text { chip analysis } \\
\text { validated by } \\
\text { RT-qPCR }\end{array}$ & UC & $\begin{array}{l}\text { DU145 and } \\
\text { PC3 }\end{array}$ & & Paclitaxel & $\begin{array}{l}\text { Li et al., } \\
2016\end{array}$ \\
\hline $\operatorname{miR}-598,148 a, 34 a, 146 a$ & Down & $\begin{array}{l}\text { TLDA with } \\
\text { qPCR }\end{array}$ & UC & $\begin{array}{l}\text { 22RV1, DU145 } \\
\text { and PC3 }\end{array}$ & $\begin{array}{c}\text { No for } \\
\text { chemoresis- } \\
\text { tance }\end{array}$ & Docetaxel & $\begin{array}{l}\text { Corcoran } \\
\text { et al. } 2014\end{array}$ \\
\hline $\operatorname{miR}-21$ & Up & qPCR & SEC & $\begin{array}{l}\text { LNCaP and } \\
\text { LNCaP } \\
\text { enz-resistant }\end{array}$ & $\begin{array}{l}\text { Resistant vs. } \\
\text { sensitive } \\
\text { patients }\end{array}$ & Enzalutamide & $\begin{array}{l}\text { Lee et al., } \\
\quad 2021\end{array}$ \\
\hline \multicolumn{8}{|c|}{ Protein } \\
\hline $\mathrm{Pg}-\mathrm{P}$ & Up & Western-blot & UC & PC3 & $\begin{array}{l}\text { Resistant vs. } \\
\text { therapy naive }\end{array}$ & Docetaxel & $\begin{array}{l}\text { Kato et al., } \\
2015\end{array}$ \\
\hline
\end{tabular}


Table 1. Cont.

\begin{tabular}{|c|c|c|c|c|c|c|c|}
\hline $\begin{array}{l}\text { Header Analyzed } \\
\text { molecules }\end{array}$ & $\begin{array}{l}\text { Up/Down in } \\
\text { Resistant } \\
\text { Cells or } \\
\text { Tumors }\end{array}$ & $\begin{array}{l}\text { Analysis } \\
\text { Methods }\end{array}$ & $\begin{array}{c}\text { EVs } \\
\text { Isolation }\end{array}$ & $\begin{array}{l}\text { Origin of } \\
\text { Cells EVs }\end{array}$ & $\begin{array}{c}\text { Origin of } \\
\text { Patients EVs }\end{array}$ & Drug & Reference \\
\hline Pg-P & Up & Western-blot & UC & DU-145 & $\begin{array}{l}\text { Resistant } \\
\text { versus } \\
\text { sensitive }\end{array}$ & Docetaxel & $\begin{array}{l}\text { Kharaziha } \\
\text { et al., } 2015\end{array}$ \\
\hline Pg-P & Up & Western-blot & UC & $\begin{array}{c}\text { DU- } \\
145 / 22 R V 1\end{array}$ & & Docetaxel & $\begin{array}{l}\text { Corcoran } \\
\text { et al., } 2012 \\
\end{array}$ \\
\hline Vinculine, ITGB4 & Up & $\begin{array}{l}\text { LC-MALDI- } \\
\text { TOF }\end{array}$ & UC & PC3 & & $\begin{array}{l}\text { Taxane (pacli- } \\
\text { taxel/docetaxel) }\end{array}$ & $\begin{array}{l}\text { Kawakami } \\
\text { et al., } 2015\end{array}$ \\
\hline TSP1 & Up & Western-blot & $\begin{array}{l}\text { UF and } \\
\text { precipita- } \\
\text { tion }\end{array}$ & LNCaP-AR & & Enzalutamide & $\begin{array}{l}\text { Bhagirath } \\
\text { et al., } 2021\end{array}$ \\
\hline $\begin{array}{c}\text { YAP1 } \\
\text { COUP-TFII }\end{array}$ & Up & Western blot & SEC & LNCaP & $\begin{array}{l}\text { Resistant vs. } \\
\text { sensitive } \\
\text { patients }\end{array}$ & Enzalutamide & $\begin{array}{l}\text { Lee et al., } \\
2021\end{array}$ \\
\hline PD-L1 & Up & $\begin{array}{l}\text { Western-blot, } \\
\text { Luminex }\end{array}$ & UC & & $\begin{array}{l}\text { Favorable vs. } \\
\text { unfavorable } \\
\text { overall } \\
\text { survival } \\
\end{array}$ & Radium-223 & $\begin{array}{l}\text { Vardaki } \\
\text { et al., } 2021\end{array}$ \\
\hline \multicolumn{8}{|c|}{ mRNA } \\
\hline CD44v8-10 mRNA & Up & RT-qPCR & UC & & $\begin{array}{l}\text { Resistant vs. } \\
\text { naive }\end{array}$ & Docetaxel & $\begin{array}{l}\text { Kato et al., } \\
\quad 2020\end{array}$ \\
\hline AR-V7 & presence & ddPCR & UC & & $\begin{array}{l}\text { Responders vs. } \\
\text { non- } \\
\text { responders }\end{array}$ & $\begin{array}{c}\text { Abiraterone, } \\
\text { enzalutamide, } \\
\text { cabazitaxel, } \\
\text { docetaxel }\end{array}$ & $\begin{array}{l}\text { Foroni } \\
\text { et al., } 2020\end{array}$ \\
\hline AR-V7 & presence & ddPCR & UC & & & $\begin{array}{c}\text { Abiraterone, } \\
\text { enzalutamide, } \\
\text { docetaxel }\end{array}$ & $\begin{array}{l}\text { Joncas } \\
\text { et al., } 2019\end{array}$ \\
\hline AR-V7 & presence & ddPCR & $\begin{array}{l}\text { Exoeasy } \\
\text { spin } \\
\text { columns }\end{array}$ & & & $\begin{array}{l}\text { Enzalutamide, } \\
\text { abiraterone }\end{array}$ & $\begin{array}{l}\text { Del Re } \\
\text { et al., } 2017 \\
\text { Del Re } \\
\text { et al., } 2021\end{array}$ \\
\hline \multicolumn{8}{|c|}{ Pathways modified } \\
\hline $\begin{array}{l}\text { Bone related pathways } \\
\text { DNA damage } \\
\text { repair-related pathways } \\
\text { Immune suppressors }\end{array}$ & & RNAseq & UC & & $\begin{array}{l}\text { Favorable vs. } \\
\text { unfavorable } \\
\text { overall } \\
\text { survival }\end{array}$ & Radium-223 & $\begin{array}{l}\text { Vardaki } \\
\text { et al., } 2021\end{array}$ \\
\hline
\end{tabular}

\subsection{Specificities of Large Oncosomes}

Recent developments in molecular biology techniques (digital droplet PCR, New Generation Sequencing) have rendered the accurate analysis of genetic alterations from tumor DNA (tDNA) possible. The amount of circulating tDNA (ctDNA) in plasma is proportional to the tumor mass and the overall shorter survival of CRPC patients [113]. The use of ctDNA as a non-invasive and specific blood biomarker could therefore represent an attractive approach to monitoring the evolution of the disease and to offering personalized treatments to CRPC patients. However, ctDNA in men with metastatic prostate cancer is rapidly reduced with ADT, thus limiting the detection of clinically relevant somatic mutations and subsequently compromising the use of ctDNA [114]. Furthermore, the half-life of ctDNA is relatively short $(<2 \mathrm{~h})$ since this DNA is subject to degradation by DNAses.

Recently, EVs have been shown to contain double stranded DNA carrying mutations identical to those found in parental tumor cells [115-117]. Certain genetic alterations such as TP53 or PTEN have thus been identified [118], suggesting that EVs contain genomic signatures characteristic of the cells from which they are derived. Moreover, it has been 
suggested that molecules present in EVs such as DNA and RNA are more stable as they are protected from enzymatic degradations [119].

A recent study on a small number of blood samples from CRPC patients has shown the possibility of isolating tDNA from large extracellular vesicles also called large oncosomes (LOs) [120]. Di Vizio's group reported LOs to be specifically secreted by prostate tumor cells at a quantifiable rate [37]. Purified from tumor cells, they promote the migratory and invasive capacities of recipient cells [37,121]. LOs have been detected in tumor tissues and plasma of patients with metastatic PCa. Their number is directly correlated with aggressiveness of the disease [38,122].

LOs appear to be more promising for a future clinical use. With a diameter of 1 to $10 \mu \mathrm{m}$, they are 100 to 1000 times larger than exosomes and contain proteins, RNA and DNA [123]. Moreover, LOs have also been shown to be a subpopulation of EVs containing DNA with tumor-specific molecular content [122]. DNA purified from LOs issued from CRPC patient plasma is of high molecular weight (100 kbp-2 Mbp) and contains histones, hence suggesting the presence of intact chromosomes in these vesicles. This DNA appears to be specific since it is absent and not detected in the EVs of healthy subjects. NGS sequencing has shown that LOs DNA contains the same genetic alterations as those found in tumor tissue, such as variations in the copy number of genes frequently altered in CRPC (MYC, AKT1, PTK2, KLF10 and PTEN) [120].

A recent study described the possibility to purify circulating tumor cells and LOs in order to confer a higher sensitivity to the liquid biopsy assay in the case of CRPC. CTCs and LEVs could be discriminated based on size, morphology and DNA content [124].

\subsection{Future of EVs Biomarkers}

Several clinical studies using EVs content as biomarkers are conducted nowadays and, more particularly, on PCa diagnosis (exosome Dx; Sentinel ${ }^{\mathrm{TM}}$ PCC4 Assay, ClarityDX Prostate) [125]. Concerning therapeutic resistance, very few studies are in process. A clinical study is currently investigating the possible use of AR-V7 for predicting resistance under androgen-receptor signaling inhibitors (PEARL, NCT03601143).

If $\mathrm{EV}$ content appears as a promising source of biomarkers, their characterization and isolation methods need to be improved. Indeed, it remains challenging to isolate EVs from contaminants such as proteins without reducing the quantity of material needed for further analysis. In addition, gold standard methods have to be established in order to be applied in a clinical context [126]. Furthermore, it still remains difficult to discriminate between different EVs such as microvesicles and exosomes.

\section{Conclusions}

In advanced $\mathrm{PCa}$, understanding the mechanisms of therapeutic resistance and finding new predictive biomarkers for therapeutic sensitivity are currently two of the main challenges for research. For years, the interest of EVs studied as tools to discover biomarkers and communication tools for cells has been growing. Their roles in the induction of therapeutic resistance in advanced prostate cancer began to be more detailed.

In the near future, EVs should allow a better understanding of the different mechanisms involved in therapeutic resistance. Moreover, their employment as tools for predictive biomarkers may allow personalized medicine in the field of many cancers, including prostate cancer.

Author Contributions: C.S., A.M., E.B., E.H., A.d.l.T., F.V., V.F. and D.D. have contributed equally to this work. All authors have read and agreed to the published version of the manuscript.

Funding: This work was supported by the University of Paris-Est Créteil and grants from the Ligue contre le cancer 94/Val-de-Marne (grant \#A.P. 2020) and the Groupement d'Entreprises Françaises dans la Lutte contre le Cancer, GEFLUC) (grant \#A.P. 2020).

Institutional Review Board Statement: Not applicable. 
Informed Consent Statement: Not applicable.

Data Availability Statement: Not applicable.

Conflicts of Interest: The authors declare no conflict of interest.

\section{References}

1. Bray, F.; Ferlay, J.; Soerjomataram, I.; Siegel, R.L.; Torre, L.A.; Jemal, A. Global cancer statistics 2018: GLOBOCAN estimates of incidence and mortality worldwide for 36 cancers in 185 countries. CA Cancer J. Clin. 2018, 68, 394-424. [CrossRef]

2. Huggins, C.; Hodges, C.V. Studies on prostatic cancer: I. The effect of castration, of estrogen and androgen injection on serum phosphatases in metastatic carcinoma of the prostate. CA Cancer J. Clin. 1972, 22, 232-240. [CrossRef]

3. Sweeney, C.J.; Chen, Y.H.; Carducci, M.; Liu, G.; Jarrard, D.F.; Eisenberger, M.; Wong, Y.N.; Hahn, N.; Kohli, M.; Cooney, M.M.; et al. Chemohormonal Therapy in Metastatic Hormone-Sensitive Prostate Cancer. N. Engl. J. Med. 2015, 373, 737-746. [CrossRef]

4. James, N.D.; Sydes, M.R.; Clarke, N.W.; Mason, M.D.; Parmar, M.K. STAMPEDE trial and patients with non-metastatic prostate cancer-Authors' reply. Lancet 2016, 388, 235-236. [CrossRef]

5. Gravis, G.; Fizazi, K.; Joly, F.; Oudard, S.; Priou, F.; Esterni, B.; Latorzeff, I.; Delva, R.; Krakowski, I.; Laguerre, B.; et al. Androgendeprivation therapy alone or with docetaxel in non-castrate metastatic prostate cancer (GETUG-AFU 15): A randomised, open-label, phase 3 trial. Lancet Oncol. 2013, 14, 149-158. [CrossRef]

6. Heidenreich, A.; Bastian, P.J.; Bellmunt, J.; Bolla, M.; Joniau, S.; van der Kwast, T.; Mason, M.; Matveev, V.; Wiegel, T.; Zattoni, F.; et al. EAU guidelines on prostate cancer. Part II: Treatment of advanced, relapsing, and castration-resistant prostate cancer. Eur. Urol. 2014, 65, 467-479. [CrossRef] [PubMed]

7. Petrylak, D.P.; Tangen, C.M.; Hussain, M.H.; Lara, P.N., Jr.; Jones, J.A.; Taplin, M.E.; Burch, P.A.; Berry, D.; Moinpour, C.; Kohli, M.; et al. Docetaxel and estramustine compared with mitoxantrone and prednisone for advanced refractory prostate cancer. $N$. Engl. J. Med. 2004, 351, 1513-1520. [CrossRef] [PubMed]

8. Tannock, I.F.; de Wit, R.; Berry, W.R.; Horti, J.; Pluzanska, A.; Chi, K.N.; Oudard, S.; Theodore, C.; James, N.D.; Turesson, I.; et al. Docetaxel plus prednisone or mitoxantrone plus prednisone for advanced prostate cancer. N. Engl. J. Med. 2004, 351, $1502-1512$. [CrossRef] [PubMed]

9. Kyriakopoulos, C.E.; Chen, Y.H.; Carducci, M.A.; Liu, G.; Jarrard, D.F.; Hahn, N.M.; Shevrin, D.H.; Dreicer, R.; Hussain, M.; Eisenberger, M.; et al. Chemohormonal Therapy in Metastatic Hormone-Sensitive Prostate Cancer: Long-Term Survival Analysis of the Randomized Phase III E3805 CHAARTED Trial. J. Clin. Oncol. 2018, 36, 1080-1087. [CrossRef]

10. de Bono, J.S.; Oudard, S.; Ozguroglu, M.; Hansen, S.; Machiels, J.P.; Kocak, I.; Gravis, G.; Bodrogi, I.; Mackenzie, M.J.; Shen, L.; et al. Prednisone plus cabazitaxel or mitoxantrone for metastatic castration-resistant prostate cancer progressing after docetaxel treatment: A randomised open-label trial. Lancet 2010, 376, 1147-1154. [CrossRef]

11. Oudard, S.; Fizazi, K.; Sengelov, L.; Daugaard, G.; Saad, F.; Hansen, S.; Hjalm-Eriksson, M.; Jassem, J.; Thiery-Vuillemin, A.; Caffo, O.; et al. Cabazitaxel Versus Docetaxel As First-Line Therapy for Patients With Metastatic Castration-Resistant Prostate Cancer: A Randomized Phase III Trial-FIRSTANA. J. Clin. Oncol. 2017, 35, 3189-3197. [CrossRef]

12. Yin, L.; Hu, Q. CYP17 inhibitors-Abiraterone, C17,20-lyase inhibitors and multi-targeting agents. Nat. Rev. Urol. 2014, 11, 32-42. [CrossRef]

13. Liu, C.; Armstrong, C.M.; Ning, S.; Yang, J.C.; Lou, W.; Lombard, A.P.; Zhao, J.; Wu, C.Y.; Yu, A.; Evans, C.P.; et al. ARVib suppresses growth of advanced prostate cancer via inhibition of androgen receptor signaling. Oncogene 2021. [CrossRef] [PubMed]

14. de Bono, J.S.; Logothetis, C.J.; Molina, A.; Fizazi, K.; North, S.; Chu, L.; Chi, K.N.; Jones, R.J.; Goodman, O.B., Jr.; Saad, F.; et al. Abiraterone and increased survival in metastatic prostate cancer. N. Engl. J. Med. 2011, 364, 1995-2005. [CrossRef]

15. Ryan, C.J.; Smith, M.R.; de Bono, J.S.; Molina, A.; Logothetis, C.J.; de Souza, P.; Fizazi, K.; Mainwaring, P.; Piulats, J.M.; Ng, S.; et al. Abiraterone in metastatic prostate cancer without previous chemotherapy. N. Engl. J. Med. 2013, 368, 138-148. [CrossRef]

16. James, N.D.; de Bono, J.S.; Spears, M.R.; Clarke, N.W.; Mason, M.D.; Dearnaley, D.P.; Ritchie, A.W.S.; Amos, C.L.; Gilson, C.; Jones, R.J.; et al. Abiraterone for Prostate Cancer Not Previously Treated with Hormone Therapy. N. Engl. J. Med. 2017, 377, 338-351. [CrossRef]

17. Fizazi, K.; Tran, N.; Fein, L.; Matsubara, N.; Rodriguez-Antolin, A.; Alekseev, B.Y.; Ozguroglu, M.; Ye, D.; Feyerabend, S.; Protheroe, A.; et al. Abiraterone plus Prednisone in Metastatic, Castration-Sensitive Prostate Cancer. N. Engl. J. Med. 2017, 377, 352-360. [CrossRef] [PubMed]

18. Scher, H.I.; Fizazi, K.; Saad, F.; Taplin, M.E.; Sternberg, C.N.; Miller, K.; de Wit, R.; Mulders, P.; Chi, K.N.; Shore, N.D.; et al. Increased survival with enzalutamide in prostate cancer after chemotherapy. N. Engl. J. Med. 2012, 367, 1187-1197. [CrossRef] [PubMed]

19. Fizazi, K.; Scher, H.I.; Miller, K.; Basch, E.; Sternberg, C.N.; Cella, D.; Forer, D.; Hirmand, M.; de Bono, J.S. Effect of enzalutamide on time to first skeletal-related event, pain, and quality of life in men with castration-resistant prostate cancer: Results from the randomised, phase 3 AFFIRM trial. Lancet Oncol. 2014, 15, 1147-1156. [CrossRef]

20. Beer, T.M.; Armstrong, A.J.; Rathkopf, D.E.; Loriot, Y.; Sternberg, C.N.; Higano, C.S.; Iversen, P.; Bhattacharya, S.; Carles, J.; Chowdhury, S.; et al. Enzalutamide in metastatic prostate cancer before chemotherapy. N. Engl. J. Med. 2014, 371, 424-433. [CrossRef] 
21. Davis, I.D.; Martin, A.J.; Stockler, M.R.; Begbie, S.; Chi, K.N.; Chowdhury, S.; Coskinas, X.; Frydenberg, M.; Hague, W.E.; Horvath, L.G.; et al. Enzalutamide with Standard First-Line Therapy in Metastatic Prostate Cancer. N. Engl. J. Med. 2019, 381, 121-131. [CrossRef]

22. Chi, K.N.; Agarwal, N.; Bjartell, A.; Chung, B.H.; Pereira de Santana Gomes, A.J.; Given, R.; Soto, A.J.; Merseburger, A.S.; Ozguroglu, M.; Uemura, H.; et al. Apalutamide for Metastatic, Castration-Sensitive Prostate Cancer. N. Engl. J. Med. 2019, 381, 13-24. [CrossRef]

23. Parker, C.C.; Pascoe, S.; Chodacki, A.; O'Sullivan, J.M.; Germa, J.R.; O’Bryan-Tear, C.G.; Haider, T.; Hoskin, P. A randomized, double-blind, dose-finding, multicenter, phase 2 study of radium chloride (Ra 223) in patients with bone metastases and castration-resistant prostate cancer. Eur. Urol. 2013, 63, 189-197. [CrossRef]

24. Harris, W.P.; Mostaghel, E.A.; Nelson, P.S.; Montgomery, B. Androgen deprivation therapy: Progress in understanding mechanisms of resistance and optimizing androgen depletion. Nat. Clin. Pract. Urol. 2009, 6, 76-85. [CrossRef] [PubMed]

25. Thery, C.; Amigorena, S.; Raposo, G.; Clayton, A. Isolation and characterization of exosomes from cell culture supernatants and biological fluids. Curr. Protoc. Cell Biol. 2006, 30, 3-22. [CrossRef] [PubMed]

26. Chargaff, E.; West, R. The biological significance of the thromboplastic protein of blood. J. Biol. Chem. 1946, 166, 189-197. [CrossRef]

27. Wolf, P. The nature and significance of platelet products in human plasma. Br. J. Haematol 1967, 13, 269-288. [CrossRef] [PubMed]

28. Harding, C.; Heuser, J.; Stahl, P. Receptor-mediated endocytosis of transferrin and recycling of the transferrin receptor in rat reticulocytes. J. Cell Biol. 1983, 97, 329-339. [CrossRef] [PubMed]

29. Johnstone, R.M.; Adam, M.; Hammond, J.R.; Orr, L.; Turbide, C. Vesicle formation during reticulocyte maturation. Association of plasma membrane activities with released vesicles (exosomes). J. Biol. Chem. 1987, 262, 9412-9420. [CrossRef]

30. Pan, B.T.; Johnstone, R.M. Fate of the transferrin receptor during maturation of sheep reticulocytes in vitro: Selective externalization of the receptor. Cell 1983, 33, 967-978. [CrossRef]

31. Cocucci, E.; Racchetti, G.; Meldolesi, J. Shedding microvesicles: Artefacts no more. Trends Cell Biol. 2009, 19, 43-51. [CrossRef]

32. Thebaud, B.; Stewart, D.J. Exosomes: Cell garbage can, therapeutic carrier, or trojan horse? Circulation 2012, 126, 2553-2555. [CrossRef]

33. Thery, C.; Witwer, K.W.; Aikawa, E.; Alcaraz, M.J.; Anderson, J.D.; Andriantsitohaina, R.; Antoniou, A.; Arab, T.; Archer, F.; Atkin-Smith, G.K.; et al. Minimal information for studies of extracellular vesicles 2018 (MISEV2018): A position statement of the International Society for Extracellular Vesicles and update of the MISEV2014 guidelines. J. Extracell. Vesicles 2018, 7, 1535750. [CrossRef]

34. Colombo, M.; Raposo, G.; Thery, C. Biogenesis, secretion, and intercellular interactions of exosomes and other extracellular vesicles. Annu. Rev. Cell Dev. Biol. 2014, 30, 255-289. [CrossRef]

35. van Niel, G.; D'Angelo, G.; Raposo, G. Shedding light on the cell biology of extracellular vesicles. Nat. Rev. Mol. Cell Biol. 2018, 19, 213-228. [CrossRef]

36. Raposo, G.; Stoorvogel, W. Extracellular vesicles: Exosomes, microvesicles, and friends. J. Cell Biol. 2013, 200, 373-383. [CrossRef]

37. Di Vizio, D.; Kim, J.; Hager, M.H.; Morello, M.; Yang, W.; Lafargue, C.J.; True, L.D.; Rubin, M.A.; Adam, R.M.; Beroukhim, R.; et al. Oncosome formation in prostate cancer: Association with a region of frequent chromosomal deletion in metastatic disease. Cancer Res. 2009, 69, 5601-5609. [CrossRef]

38. Di Vizio, D.; Morello, M.; Dudley, A.C.; Schow, P.W.; Adam, R.M.; Morley, S.; Mulholland, D.; Rotinen, M.; Hager, M.H.; Insabato, L.; et al. Large oncosomes in human prostate cancer tissues and in the circulation of mice with metastatic disease. Am. J. Pathol. 2012, 181, 1573-1584. [CrossRef]

39. Yanez-Mo, M.; Siljander, P.R.; Andreu, Z.; Zavec, A.B.; Borras, F.E.; Buzas, E.I.; Buzas, K.; Casal, E.; Cappello, F.; Carvalho, J.; et al. Biological properties of extracellular vesicles and their physiological functions. J. Extracell. Vesicles 2015, 4, 27066. [CrossRef] [PubMed]

40. Trajkovic, K.; Hsu, C.; Chiantia, S.; Rajendran, L.; Wenzel, D.; Wieland, F.; Schwille, P.; Brugger, B.; Simons, M. Ceramide triggers budding of exosome vesicles into multivesicular endosomes. Science 2008, 319, 1244-1247. [CrossRef]

41. Buschow, S.I.; Nolte-'t Hoen, E.N.; van Niel, G.; Pols, M.S.; ten Broeke, T.; Lauwen, M.; Ossendorp, F.; Melief, C.J.; Raposo, G.; Wubbolts, R.; et al. MHC II in dendritic cells is targeted to lysosomes or T cell-induced exosomes via distinct multivesicular body pathways. Traffic 2009, 10, 1528-1542. [CrossRef]

42. Coumans, F.A.W.; Brisson, A.R.; Buzas, E.I.; Dignat-George, F.; Drees, E.E.E.; El-Andaloussi, S.; Emanueli, C.; Gasecka, A.; Hendrix, A.; Hill, A.F.; et al. Methodological Guidelines to Study Extracellular Vesicles. Circ. Res. 2017, 120, 1632-1648. [CrossRef] [PubMed]

43. Caby, M.P.; Lankar, D.; Vincendeau-Scherrer, C.; Raposo, G.; Bonnerot, C. Exosomal-like vesicles are present in human blood plasma. Int. Immunol. 2005, 17, 879-887. [CrossRef]

44. Arraud, N.; Linares, R.; Tan, S.; Gounou, C.; Pasquet, J.M.; Mornet, S.; Brisson, A.R. Extracellular vesicles from blood plasma: Determination of their morphology, size, phenotype and concentration. J. Thromb. Haemost. 2014, 12, 614-627. [CrossRef] [PubMed]

45. Gonzales, P.A.; Zhou, H.; Pisitkun, T.; Wang, N.S.; Star, R.A.; Knepper, M.A.; Yuen, P.S. Isolation and purification of exosomes in urine. Methods Mol. Biol. 2010, 641, 89-99. [CrossRef] 
46. Palanisamy, V.; Sharma, S.; Deshpande, A.; Zhou, H.; Gimzewski, J.; Wong, D.T. Nanostructural and transcriptomic analyses of human saliva derived exosomes. PLoS ONE 2010, 5, e8577. [CrossRef]

47. Admyre, C.; Johansson, S.M.; Qazi, K.R.; Filen, J.J.; Lahesmaa, R.; Norman, M.; Neve, E.P.; Scheynius, A.; Gabrielsson, S. Exosomes with immune modulatory features are present in human breast milk. J. Immunol. 2007, 179, 1969-1978. [CrossRef]

48. Lasser, C.; O'Neil, S.E.; Ekerljung, L.; Ekstrom, K.; Sjostrand, M.; Lotvall, J. RNA-containing exosomes in human nasal secretions. Am. J. Rhinol. allergy 2011, 25, 89-93. [CrossRef]

49. Koga, Y.; Yasunaga, M.; Moriya, Y.; Akasu, T.; Fujita, S.; Yamamoto, S.; Matsumura, Y. Exosome can prevent RNase from degrading microRNA in feces. J. Gastrointest. Oncol. 2011, 2, 215-222. [CrossRef] [PubMed]

50. Aalberts, M.; Sostaric, E.; Wubbolts, R.; Wauben, M.W.; Nolte-'t Hoen, E.N.; Gadella, B.M.; Stout, T.A.; Stoorvogel, W. Spermatozoa recruit prostasomes in response to capacitation induction. Biochim. Biophys. Acta 2013, 1834, 2326-2335. [CrossRef]

51. Ronquist, G.K.; Larsson, A.; Stavreus-Evers, A.; Ronquist, G. Prostasomes are heterogeneous regarding size and appearance but affiliated to one DNA-containing exosome family. Prostate 2012, 72, 1736-1745. [CrossRef] [PubMed]

52. Duijvesz, D.; Luider, T.; Bangma, C.H.; Jenster, G. Exosomes as biomarker treasure chests for prostate cancer. Eur. Urol. 2011, 59, 823-831. [CrossRef] [PubMed]

53. Pons-Rejraji, H.; Artonne, C.; Sion, B.; Brugnon, F.; Canis, M.; Janny, L.; Grizard, G. Prostasomes: Inhibitors of capacitation and modulators of cellular signalling in human sperm. Int. J. Androl. 2011, 34, 568-580. [CrossRef]

54. Laxman, B.; Morris, D.S.; Yu, J.; Siddiqui, J.; Cao, J.; Mehra, R.; Lonigro, R.J.; Tsodikov, A.; Wei, J.T.; Tomlins, S.A.; et al. A first-generation multiplex biomarker analysis of urine for the early detection of prostate cancer. Cancer Res. 2008, 68, 645-649. [CrossRef]

55. Carlsson, L.; Nilsson, O.; Larsson, A.; Stridsberg, M.; Sahlen, G.; Ronquist, G. Characteristics of human prostasomes isolated from three different sources. Prostate 2003, 54, 322-330. [CrossRef]

56. Xavier, C.P.R.; Caires, H.R.; Barbosa, M.A.G.; Bergantim, R.; Guimaraes, J.E.; Vasconcelos, M.H. The Role of Extracellular Vesicles in the Hallmarks of Cancer and Drug Resistance. Cells 2020, 9, 1141. [CrossRef]

57. Read, J.; Ingram, A.; Al Saleh, H.A.; Platko, K.; Gabriel, K.; Kapoor, A.; Pinthus, J.; Majeed, F.; Qureshi, T.; Al-Nedawi, K. Nuclear transportation of exogenous epidermal growth factor receptor and androgen receptor via extracellular vesicles. Eur. J. Cancer 2017, 70, 62-74. [CrossRef]

58. Soekmadji, C.; Riches, J.D.; Russell, P.J.; Ruelcke, J.E.; McPherson, S.; Wang, C.; Hovens, C.M.; Corcoran, N.M.; The Australian Prostate Cancer Collaboration BioResource; Hill, M.M.; et al. Modulation of paracrine signaling by CD9 positive small extracellular vesicles mediates cellular growth of androgen deprived prostate cancer. Oncotarget 2017, 8, 52237-52255. [CrossRef]

59. Hosseini-Beheshti, E.; Choi, W.; Weiswald, L.B.; Kharmate, G.; Ghaffari, M.; Roshan-Moniri, M.; Hassona, M.D.; Chan, L.; Chin, M.Y.; Tai, I.T.; et al. Exosomes confer pro-survival signals to alter the phenotype of prostate cells in their surrounding environment. Oncotarget 2016, 7, 14639-14658. [CrossRef]

60. Lazaro-Ibanez, E.; Neuvonen, M.; Takatalo, M.; Arasu, U.T.; Capasso, C.; Cerullo, V.; Rhim, J.S.; Rilla, K.; Yliperttula, M.; Siljander, P.R. Metastatic state of parent cells influences the uptake and functionality of prostate cancer cell-derived extracellular vesicles. J. Extracell. Vesicles 2017, 6, 1354645. [CrossRef]

61. Fedele, C.; Singh, A.; Zerlanko, B.J.; Iozzo, R.V.; Languino, L.R. The alphavbeta6 integrin is transferred intercellularly via exosomes. J. Biol. Chem. 2015, 290, 4545-4551. [CrossRef] [PubMed]

62. Krishn, S.R.; Singh, A.; Bowler, N.; Duffy, A.N.; Friedman, A.; Fedele, C.; Kurtoglu, S.; Tripathi, S.K.; Wang, K.; Hawkins, A.; et al. Prostate cancer sheds the alphavbeta3 integrin in vivo through exosomes. Matrix Biol. 2019, 77, 41-57. [CrossRef] [PubMed]

63. Poggio, M.; Hu, T.; Pai, C.C.; Chu, B.; Belair, C.D.; Chang, A.; Montabana, E.; Lang, U.E.; Fu, Q.; Fong, L.; et al. Suppression of Exosomal PD-L1 Induces Systemic Anti-tumor Immunity and Memory. Cell 2019, 177, 414-427 e413. [CrossRef] [PubMed]

64. Galletti, G.; Leach, B.I.; Lam, L.; Tagawa, S.T. Mechanisms of resistance to systemic therapy in metastatic castration-resistant prostate cancer. Cancer Treat. Rev. 2017, 57, 16-27. [CrossRef]

65. Ceder, Y.; Bjartell, A.; Culig, Z.; Rubin, M.A.; Tomlins, S.; Visakorpi, T. The Molecular Evolution of Castration-resistant Prostate Cancer. Eur. Urol. Focus 2016, 2, 506-513. [CrossRef]

66. Soekmadji, C.; Rockstroh, A.; Ramm, G.A.; Nelson, C.C.; Russell, P.J. Extracellular Vesicles in the Adaptive Process of Prostate Cancer during Inhibition of Androgen Receptor Signaling by Enzalutamide. Proteomics 2017, 17, 1600427. [CrossRef]

67. Zhang, Y.; Chen, B.; Xu, N.; Xu, P.; Lin, W.; Liu, C.; Huang, P. Exosomes Promote the Transition of Androgen-Dependent Prostate Cancer Cells into Androgen-Independent Manner Through Up-Regulating the Heme Oxygenase-1. Int. J. Nanomed. 2021, 16, 315-327. [CrossRef] [PubMed]

68. Alaoui-Jamali, M.A.; Bismar, T.A.; Gupta, A.; Szarek, W.A.; Su, J.; Song, W.; Xu, Y.; Xu, B.; Liu, G.; Vlahakis, J.Z.; et al. A novel experimental heme oxygenase-1-targeted therapy for hormone-refractory prostate cancer. Cancer Res. 2009, 69, 8017-8024. [CrossRef]

69. Gregory, C.W.; He, B.; Wilson, E.M. The putative androgen receptor-A form results from in vitro proteolysis. J. Mol. Endocrinol. 2001, 27, 309-319. [CrossRef]

70. Zhu, Y.; Luo, J. Regulation of androgen receptor variants in prostate cancer. Asian J. Urol. 2020, 7, 251-257. [CrossRef]

71. Chen, X.; Bernemann, C.; Tolkach, Y.; Heller, M.; Nientiedt, C.; Falkenstein, M.; Herpel, E.; Jenzer, M.; Grullich, C.; Jager, D.; et al. Overexpression of nuclear AR-V7 protein in primary prostate cancer is an independent negative prognostic marker in men with high-risk disease receiving adjuvant therapy. Urol. Oncol. 2018, 36, 161.e119-161.e130. [CrossRef] 
72. Del Re, M.; Biasco, E.; Crucitta, S.; Derosa, L.; Rofi, E.; Orlandini, C.; Miccoli, M.; Galli, L.; Falcone, A.; Jenster, G.W.; et al. The Detection of Androgen Receptor Splice Variant 7 in Plasma-derived Exosomal RNA Strongly Predicts Resistance to Hormonal Therapy in Metastatic Prostate Cancer Patients. Eur. Urol. 2017, 71, 680-687. [CrossRef] [PubMed]

73. Joncas, F.H.; Lucien, F.; Rouleau, M.; Morin, F.; Leong, H.S.; Pouliot, F.; Fradet, Y.; Gilbert, C.; Toren, P. Plasma extracellular vesicles as phenotypic biomarkers in prostate cancer patients. Prostate 2019, 79, 1767-1776. [CrossRef] [PubMed]

74. Strati, A.; Zavridou, M.; Bournakis, E.; Mastoraki, S.; Lianidou, E. Expression pattern of androgen receptors, AR-V7 and AR-567es, in circulating tumor cells and paired plasma-derived extracellular vesicles in metastatic castration resistant prostate cancer. Analyst 2019, 144, 6671-6680. [CrossRef] [PubMed]

75. Shedden, K.; Xie, X.T.; Chandaroy, P.; Chang, Y.T.; Rosania, G.R. Expulsion of small molecules in vesicles shed by cancer cells: Association with gene expression and chemosensitivity profiles. Cancer Res. 2003, 63, 4331-4337. [PubMed]

76. Kosgodage, U.S.; Trindade, R.P.; Thompson, P.R.; Inal, J.M.; Lange, S. Chloramidine/Bisindolylmaleimide-I-Mediated Inhibition of Exosome and Microvesicle Release and Enhanced Efficacy of Cancer Chemotherapy. Int. J. Mol. Sci. 2017, 18, 1007. [CrossRef]

77. Jorfi, S.; Ansa-Addo, E.A.; Kholia, S.; Stratton, D.; Valley, S.; Lange, S.; Inal, J. Inhibition of microvesiculation sensitizes prostate cancer cells to chemotherapy and reduces docetaxel dose required to limit tumor growth in vivo. Sci. Rep. 2015, 5, 13006. [CrossRef]

78. Kawanobe, T.; Kogure, S.; Nakamura, S.; Sato, M.; Katayama, K.; Mitsuhashi, J.; Noguchi, K.; Sugimoto, Y. Expression of human ABCB5 confers resistance to taxanes and anthracyclines. Biochem. Biophys Res. Commun. 2012, 418, 736-741. [CrossRef]

79. Zhu, Y.; Liu, C.; Nadiminty, N.; Lou, W.; Tummala, R.; Evans, C.P.; Gao, A.C. Inhibition of ABCB1 expression overcomes acquired docetaxel resistance in prostate cancer. Mol. Cancer Ther. 2013, 12, 1829-1836. [CrossRef]

80. Lucotti, S.; Rainaldi, G.; Evangelista, M.; Rizzo, M. Fludarabine treatment favors the retention of miR-485-3p by prostate cancer cells: Implications for survival. Mol. Cancer 2013, 12, 52. [CrossRef]

81. Kharaziha, P.; Chioureas, D.; Rutishauser, D.; Baltatzis, G.; Lennartsson, L.; Fonseca, P.; Azimi, A.; Hultenby, K.; Zubarev, R.; Ullen, A.; et al. Molecular profiling of prostate cancer derived exosomes may reveal a predictive signature for response to docetaxel. Oncotarget 2015, 6, 21740-21754. [CrossRef] [PubMed]

82. Corcoran, C.; Rani, S.; O’Brien, K.; O’Neill, A.; Prencipe, M.; Sheikh, R.; Webb, G.; McDermott, R.; Watson, W.; Crown, J.; et al. Docetaxel-resistance in prostate cancer: Evaluating associated phenotypic changes and potential for resistance transfer via exosomes. PLoS ONE 2012, 7, e50999. [CrossRef]

83. Panagopoulos, K.; Cross-Knorr, S.; Dillard, C.; Pantazatos, D.; Del Tatto, M.; Mills, D.; Goldstein, L.; Renzulli, J.; Quesenberry, P.; Chatterjee, D. Reversal of chemosensitivity and induction of cell malignancy of a non-malignant prostate cancer cell line upon extracellular vesicle exposure. Mol. Cancer 2013, 12, 118. [CrossRef]

84. Wang, J.Q.; DeChalus, A.; Chatterjee, D.N.; Keller, E.T.; Mizokami, A.; Camussi, G.; Mendelsohn, A.R.; Ii, J.F.R.; Quesenberry, P.J.; Chatterjee, D. Extracellular Vesicle-Mediated Reversal of Paclitaxel Resistance in Prostate Cancer. Crit. Rev. Oncog. 2015, 20, 407-417. [CrossRef] [PubMed]

85. Peak, T.C.; Panigrahi, G.K.; Praharaj, P.P.; Su, Y.; Shi, L.; Chyr, J.; Rivera-Chavez, J.; Flores-Bocanegra, L.; Singh, R.; Griend, D.J.V.; et al. Syntaxin 6-mediated exosome secretion regulates enzalutamide resistance in prostate cancer. Mol. Carcinog. 2020, 59, 62-72. [CrossRef] [PubMed]

86. Li, J.; Yang, X.; Guan, H.; Mizokami, A.; Keller, E.T.; Xu, X.; Liu, X.; Tan, J.; Hu, L.; Lu, Y.; et al. Exosome-derived microRNAs contribute to prostate cancer chemoresistance. Int. J. Oncol. 2016, 49, 838-846. [CrossRef] [PubMed]

87. Smith, B.N.; Bhowmick, N.A. Role of EMT in Metastasis and Therapy Resistance. J. Clin. Med. 2016, 5, 17. [CrossRef]

88. Terry, S.; El-Sayed, I.Y.; Destouches, D.; Maille, P.; Nicolaiew, N.; Ploussard, G.; Semprez, F.; Pimpie, C.; Beltran, H.; LondonoVallejo, A.; et al. CRIPTO overexpression promotes mesenchymal differentiation in prostate carcinoma cells through parallel regulation of AKT and FGFR activities. Oncotarget 2015, 6, 11994-12008. [CrossRef]

89. El-Sayed, I.Y.; Daher, A.; Destouches, D.; Firlej, V.; Kostallari, E.; Maille, P.; Huet, E.; Haidar-Ahmad, N.; Jenster, G.; de la Taille, A.; et al. Extracellular vesicles released by mesenchymal-like prostate carcinoma cells modulate EMT state of recipient epithelial-like carcinoma cells through regulation of AR signaling. Cancer Lett. 2017, 410, 100-111. [CrossRef]

90. Lin, C.J.; Yun, E.J.; Lo, U.G.; Tai, Y.L.; Deng, S.; Hernandez, E.; Dang, A.; Chen, Y.A.; Saha, D.; Mu, P.; et al. The paracrine induction of prostate cancer progression by caveolin-1. Cell Death Dis. 2019, 10, 834. [CrossRef]

91. Davies, A.H.; Beltran, H.; Zoubeidi, A. Cellular plasticity and the neuroendocrine phenotype in prostate cancer. Nat. Rev. Urol. 2018, 15, 271-286. [CrossRef]

92. Beltran, H.; Hruszkewycz, A.; Scher, H.I.; Hildesheim, J.; Isaacs, J.; Yu, E.Y.; Kelly, K.; Lin, D.; Dicker, A.; Arnold, J.; et al. The Role of Lineage Plasticity in Prostate Cancer Therapy Resistance. Clin. Cancer Res. 2019, 25, 6916-6924. [CrossRef] [PubMed]

93. Roubaud, G.; Liaw, B.C.; Oh, W.K.; Mulholland, D.J. Strategies to avoid treatment-induced lineage crisis in advanced prostate cancer. Nat. Rev. Clin. Oncol. 2017, 14, 269-283. [CrossRef]

94. Lin, L.C.; Gao, A.C.; Lai, C.H.; Hsieh, J.T.; Lin, H. Induction of neuroendocrine differentiation in castration resistant prostate cancer cells by adipocyte differentiation-related protein (ADRP) delivered by exosomes. Cancer Lett. 2017, 391, 74-82. [CrossRef] [PubMed]

95. Bhagirath, D.; Yang, T.L.; Tabatabai, Z.L.; Majid, S.; Dahiya, R.; Tanaka, Y.; Saini, S. BRN4 Is a Novel Driver of Neuroendocrine Differentiation in Castration-Resistant Prostate Cancer and Is Selectively Released in Extracellular Vesicles with BRN2. Clin. Cancer Res. 2019, 25, 6532-6545. [CrossRef] [PubMed] 
96. Kita, Y.; Goto, T.; Akamatsu, S.; Yamasaki, T.; Inoue, T.; Ogawa, O.; Kobayashi, T. Castration-Resistant Prostate Cancer Refractory to Second-Generation Androgen Receptor Axis-Targeted Agents: Opportunities and Challenges. Cancers 2018, 10, 345. [CrossRef] [PubMed]

97. Mostafazadeh, M.; Samadi, N.; Kahroba, H.; Baradaran, B.; Haiaty, S.; Nouri, M. Potential roles and prognostic significance of exosomes in cancer drug resistance. Cell BioSci. 2021, 11, 1. [CrossRef] [PubMed]

98. Zhang, Y.; Zhao, J.; Ding, M.; Su, Y.; Cui, D.; Jiang, C.; Zhao, S.; Jia, G.; Wang, X.; Ruan, Y.; et al. Loss of exosomal miR-146a-5p from cancer-associated fibroblasts after androgen deprivation therapy contributes to prostate cancer metastasis. J. Exp. Clin. Cancer Res. 2020, 39, 282. [CrossRef]

99. Cao, Z.; Xu, L.; Zhao, S. Exosome-derived miR-27a produced by PSC-27cells contributes to prostate cancer chemoresistance through p53. BioChem. Biophys. Res. Commun. 2019, 515, 345-351. [CrossRef]

100. Shan, G.; Gu, J.; Zhou, D.; Li, L.; Cheng, W.; Wang, Y.; Tang, T.; Wang, X. Cancer-associated fibroblast-secreted exosomal miR-423-5p promotes chemotherapy resistance in prostate cancer by targeting GREM2 through the TGF-beta signaling pathway. Exp. Mol. Med. 2020, 52, 1809-1822. [CrossRef]

101. Wang, J.; Ni, J.; Beretov, J.; Thompson, J.; Graham, P.; Li, Y. Exosomal microRNAs as liquid biopsy biomarkers in prostate cancer. Crit. Rev. Oncol. Hematol. 2020, 145, 102860. [CrossRef]

102. Dhondt, B.; Lumen, N.; De Wever, O.; Hendrix, A. Preparation of Multi-omics Grade Extracellular Vesicles by Density-Based Fractionation of Urine. STAR Protoc. 2020, 1, 100073. [CrossRef]

103. Hatano, K.; Fujita, K. Extracellular vesicles in prostate cancer: A narrative review. Transl. Androl. Urol. 2021, 10, 1890-1907. [CrossRef]

104. Kato, T.; Mizutani, K.; Kameyama, K.; Kawakami, K.; Fujita, Y.; Nakane, K.; Kanimoto, Y.; Ehara, H.; Ito, H.; Seishima, M.; et al. Serum exosomal P-glycoprotein is a potential marker to diagnose docetaxel resistance and select a taxoid for patients with prostate cancer. Urol. Oncol. 2015, 33, 385.e15-385.e20. [CrossRef]

105. Kato, T.; Mizutani, K.; Kawakami, K.; Fujita, Y.; Ehara, H.; Ito, M. CD44v8-10 mRNA contained in serum exosomes as a diagnostic marker for docetaxel resistance in prostate cancer patients. Heliyon 2020, 6, e04138. [CrossRef]

106. Foroni, C.; Zarovni, N.; Bianciardi, L.; Bernardi, S.; Triggiani, L.; Zocco, D.; Venturella, M.; Chiesi, A.; Valcamonico, F.; Berruti, A When Less Is More: Specific Capture and Analysis of Tumor Exosomes in Plasma Increases the Sensitivity of Liquid Biopsy for Comprehensive Detection of Multiple Androgen Receptor Phenotypes in Advanced Prostate Cancer Patients. Biomedicines 2020, 8, 131. [CrossRef]

107. Del Re, M.; Conteduca, V.; Crucitta, S.; Gurioli, G.; Casadei, C.; Restante, G.; Schepisi, G.; Lolli, C.; Cucchiara, F.; Danesi, R.; et al Androgen receptor gain in circulating free DNA and splicing variant 7 in exosomes predict clinical outcome in CRPC patients treated with abiraterone and enzalutamide. Prostate Cancer Prostatic Dis. 2021, 24, 524-531. [CrossRef]

108. Kawakami, K.; Fujita, Y.; Kato, T.; Mizutani, K.; Kameyama, K.; Tsumoto, H.; Miura, Y.; Deguchi, T.; Ito, M. Integrin beta4 and vinculin contained in exosomes are potential markers for progression of prostate cancer associated with taxane-resistance. Int. J. Oncol. 2015, 47, 384-390. [CrossRef] [PubMed]

109. Bhagirath, D.; Liston, M.; Akoto, T.; Lui, B.; Bensing, B.A.; Sharma, A.; Saini, S. Novel, non-invasive markers for detecting therapy induced neuroendocrine differentiation in castration-resistant prostate cancer patients. Sci. Rep. 2021, 11, 8279. [CrossRef] [PubMed]

110. Lee, H.C.; Ou, C.H.; Huang, Y.C.; Hou, P.C.; Creighton, C.J.; Lin, Y.S.; Hu, C.Y.; Lin, S.C. YAP1 overexpression contributes to the development of enzalutamide resistance by induction of cancer stemness and lipid metabolism in prostate cancer. Oncogene 2021, 40, 2407-2421. [CrossRef] [PubMed]

111. Vardaki, I.; Corn, P.; Gentile, E.; Song, J.H.; Madan, N.; Hoang, A.; Parikh, N.; Guerra, L.; Lee, Y.C.; Lin, S.C.; et al. Radium223 Treatment Increases Immune Checkpoint Expression in Extracellular Vesicles from the Metastatic Prostate Cancer Bone Microenvironment. Clin. Cancer Res. 2021, 27, 3253-3264. [CrossRef] [PubMed]

112. Corcoran, C.; Rani, S.; O'Driscoll, L. miR-34a is an intracellular and exosomal predictive biomarker for response to docetaxel with clinical relevance to prostate cancer progression. Prostate 2014, 74, 1320-1334. [CrossRef]

113. Annala, M.; Vandekerkhove, G.; Khalaf, D.; Taavitsainen, S.; Beja, K.; Warner, E.W.; Sunderland, K.; Kollmannsberger, C.; Eigl, B.J.; Finch, D.; et al. Circulating Tumor DNA Genomics Correlate with Resistance to Abiraterone and Enzalutamide in Prostate Cancer. Cancer Discov. 2018, 8, 444-457. [CrossRef]

114. Vandekerkhove, G.; Struss, W.J.; Annala, M.; Kallio, H.M.L.; Khalaf, D.; Warner, E.W.; Herberts, C.; Ritch, E.; Beja, K.; Loktionova, Y.; et al. Circulating Tumor DNA Abundance and Potential Utility in De Novo Metastatic Prostate Cancer. Eur. Urol. 2019, 75, 667-675. [CrossRef] [PubMed]

115. Thakur, B.K.; Zhang, H.; Becker, A.; Matei, I.; Huang, Y.; Costa-Silva, B.; Zheng, Y.; Hoshino, A.; Brazier, H.; Xiang, J.; et al. Double-stranded DNA in exosomes: A novel biomarker in cancer detection. Cell Res. 2014, 24, 766-769. [CrossRef] [PubMed]

116. Kahlert, C.; Melo, S.A.; Protopopov, A.; Tang, J.; Seth, S.; Koch, M.; Zhang, J.; Weitz, J.; Chin, L.; Futreal, A.; et al. Identification of double-stranded genomic DNA spanning all chromosomes with mutated KRAS and p53 DNA in the serum exosomes of patients with pancreatic cancer. J. Biol. Chem. 2014, 289, 3869-3875. [CrossRef]

117. Lee, T.H.; Chennakrishnaiah, S.; Meehan, B.; Montermini, L.; Garnier, D.; D'Asti, E.; Hou, W.; Magnus, N.; Gayden, T.; Jabado, N.; et al. Barriers to horizontal cell transformation by extracellular vesicles containing oncogenic H-ras. Oncotarget 2016, 7 , 51991-52002. [CrossRef] 
118. Lazaro-Ibanez, E.; Sanz-Garcia, A.; Visakorpi, T.; Escobedo-Lucea, C.; Siljander, P.; Ayuso-Sacido, A.; Yliperttula, M. Different gDNA content in the subpopulations of prostate cancer extracellular vesicles: Apoptotic bodies, microvesicles, and exosomes. Prostate 2014, 74, 1379-1390. [CrossRef]

119. Jin, Y.; Chen, K.; Wang, Z.; Wang, Y.; Liu, J.; Lin, L.; Shao, Y.; Gao, L.; Yin, H.; Cui, C.; et al. DNA in serum extracellular vesicles is stable under different storage conditions. BMC Cancer 2016, 16, 753. [CrossRef]

120. Vagner, T.; Spinelli, C.; Minciacchi, V.R.; Balaj, L.; Zandian, M.; Conley, A.; Zijlstra, A.; Freeman, M.R.; Demichelis, F.; De, S.; et al. Large extracellular vesicles carry most of the tumour DNA circulating in prostate cancer patient plasma. J. Extracell. Vesicles 2018, 7, 1505403. [CrossRef]

121. Morello, M.; Minciacchi, V.R.; de Candia, P.; Yang, J.; Posadas, E.; Kim, H.; Griffiths, D.; Bhowmick, N.; Chung, L.W.; Gandellini, P.; et al. Large oncosomes mediate intercellular transfer of functional microRNA. Cell Cycle 2013, 12, 3526-3536. [CrossRef] [PubMed]

122. Minciacchi, V.R.; Spinelli, C.; Reis-Sobreiro, M.; Cavallini, L.; You, S.; Zandian, M.; Li, X.; Mishra, R.; Chiarugi, P.; Adam, R.M.; et al. MYC Mediates Large Oncosome-Induced Fibroblast Reprogramming in Prostate Cancer. Cancer Res. 2017, 77, $2306-2317$. [CrossRef] [PubMed]

123. Pezzicoli, G.; Tucci, M.; Lovero, D.; Silvestris, F.; Porta, C.; Mannavola, F. Large Extracellular Vesicles-A New Frontier of Liquid Biopsy in Oncol.ogy. Int. J. Mol. Sci. 2020, 21, 6543. [CrossRef] [PubMed]

124. Gerdtsson, A.S.; Setayesh, S.M.; Malihi, P.D.; Ruiz, C.; Carlsson, A.; Nevarez, R.; Matsumoto, N.; Gerdtsson, E.; Zurita, A.; Logothetis, C.; et al. Large Extracellular Vesicle Characterization and Association with Circulating Tumor Cells in Metastatic Castrate Resistant Prostate Cancer. Cancers 2021, 13, 1056. [CrossRef]

125. Vlaeminck-Guillem, V. Extracellular Vesicles in Prostate Cancer Carcinogenesis, Diagnosis, and Management. Front. Oncol. 2018, 8, 222. [CrossRef]

126. Minciacchi, V.R.; Zijlstra, A.; Rubin, M.A.; Di Vizio, D. Extracellular vesicles for liquid biopsy in prostate cancer: Where are we and where are we headed? Prostate Cancer Prostatic Dis. 2017, 20, 251-258. [CrossRef] [PubMed] 